\title{
Effect of Zirconium Oxide Nano-Fillers Addition on the Flexural Strength, Fracture Toughness, and Hardness of Heat-Polymerized Acrylic Resin
}

\author{
Mohamed Ashour Ahmed1, Mohamed I. Ebrahim²,3 \\ ${ }^{1}$ Department of Prosthodontics, Faculty of Dental Medicine, Taif University, Taif, KSA \\ ${ }^{2}$ Department of Restorative Dentistry, Taif University, Taif, KSA \\ ${ }^{3}$ Department of Dental Biomaterial, Al-Azhar University, Cairo, Egypt \\ Email: drmohashour99@gmail.com
}

Received 17 March 2014; revised 17 April 2014; accepted 24 April 2014

Copyright (C) 2014 by authors and Scientific Research Publishing Inc.

This work is licensed under the Creative Commons Attribution International License (CC BY). http://creativecommons.org/licenses/by/4.0/

(c) (i) Open Access

\section{Abstract}

Purpose: The mechanical strength of polymethyl methacrylate (PMMA) remains far from ideal for maintaining the longevity of denture. The purpose of this study was to evaluate the effect of Zirconium oxide $\left(\mathrm{ZrO}_{2}\right)$ nanofillers powder with different concentration $(1.5 \%, 3 \%, 5 \%$ and $7 \%)$ on the flexural strength, fracture toughness, and hardness of heat-polymerized acrylic resin. Materials and methods: Zirconium oxide powders with different concentrations $(1.5 \%, 3 \%, 5 \%$ and $7 \%)$ were incorporated into heat-cure acrylic resin (PMMA) and processed with optimal condition (2.5:1 Powder/monomer ratio, conventional packing method and water bath curing for 2 hours at $\left.95^{\circ} \mathrm{C}\right)$ to fabricate test specimens of PMMA of dimensions (50 $\left.\times 30 \times 30 \mathrm{~mm}\right)$ for the flexural strength, fracture toughness, and (50 $\times 30 \times 30 \mathrm{~mm})$ were fabricated for measuring hardness. PMMA without additives was prepared as a test control. Three types of mechanical tests; flexural strength, fracture toughness and hardness were carried out on the samples. The recorded values of flexural strength in (MPa), fracture toughness in (MPa.m ${ }^{1 / 2}$ ), and hardness (VHN) were collected, tabulated and statistically analyzed. One way analysis of variance (ANOVA) and Tukey's tests were used for testing the significance between the means of tested groups which are statistically significant when the $P$ value $\leq \mathbf{0 . 0 5}$. Results: Addition of Zirconium oxide nanofillers to PMMA significantly increased the flexural strength, fracture toughness and hardness. Conclusion: These results indicate that Zirconium oxide nanofillers added to PMMA has a potential as a reliable denture base material with increased flexural strength, fracture toughness, and hardness. According to the results of the present study, the best mechanical properties were achieved by adding $7 \% \mathrm{wt}^{\mathrm{ZrO}} \mathrm{O}_{2}$ concentration. 


\section{Keywords}

\section{Zirconium Oxide Nano-Fillers, Flexural Strength, Fracture Toughness, Hardness, Heat-Polymerized Acrylic Resin}

\section{Introduction}

Acrylic resin polymethayl methacrylate (PMMA) has been the most popular material for the construction of dentures for many decades as it has many advantages such as good aesthetics, accurate fit, stability in the oral environment, easy laboratory and clinical manipulation, and inexpensive equipment's [1]. Although it is the most widely used in dentistry for fabrication of denture bases, this material is still insufficient to fulfill the perfect mechanical requirements for dental applications. This issue was attributed mainly to its low fracture resistance and plaque accumulation [2] [3]. In a survey to compare ten types of denture base resins it was found that nearly $70 \%$ of dentures had broken within the first 3 years of their delivery [2]. In a study evaluating the denture fracture, it was reported that $33 \%$ of the repairs were due to debonded/detached teeth, $29 \%$ of the repairs were because of midline fractures which were more commonly seen in the upper dentures and the rest were other types of fracture.

In another study the authors reported that the Mandibular partial denture was the most commonly needing repair [4]. So, the measuring of mechanical properties of the denture base materials is important to evaluate the effect of adding different strengthening materials [5].

Undoubtedly that, many trails were made to enhance mechanical properties of denture base materials either by adding chemical solutions such as a polyfunctional cross linking agent (polyethylene glycol dimethacrylate) [6] or by incorporating a rubber phase [7], metal fram [8], metal oxides [9], or fibers [10]. Despite these efforts to improve the fracture resistance of PMMA few have obtained promising results [11] [12]. The reinforcement of polymers used in dentistry with metal-composite systems has been a prime interest [12].

Zirconium oxidenano-particles powder has been selected to improve the properties of PMMA, as a bio-compatible material that possesses high fracture resistance, and to improve fracture toughness of ceramics by developing a new generation of ceramic-matrix composites [13] [14].

Since only limited amount of data regarding the effect of metal oxides on heat-cured PMMA are available in the literature, the purpose of this study was to investigate the influence of addition of metal oxides [zirconium oxide powder $\left.\left(\mathrm{ZrO}_{2}\right)\right]$ on some mechanical properties of heat cured PMMA.

\section{Materials and Methods}

An in vitro study was conducted to evaluate the effect of Zirconium oxide nanofillers powder $\left(\mathrm{ZrO}_{2}\right)(5-15 \mathrm{~nm})$ with different concentration $(1.5 \%, 3 \%, 5 \%$ and $7 \%)$ on the flexural strength, fracture toughness, and hardness of heat-polymerized acrylic resin.

One type of heat-cure acrylic resin (PMMA) was used as the control (Acrostone (A), Anglo-Egyptian Company. Hegaz, Cairo, Egypt, Batch No.505/04), Zirconium oxide nanofillers powder $\left(\mathrm{ZrO}_{2}\right)$ (Sigma-Aldrich Germany, Trade 544,760) with different concentrations (1.5\%, 3\%, 5\% and 7\%) was added into heat-cure acrylic resin (PMMA) and processed with optimal condition (2.5:1 Powder/monomer ratio, conventional packing method and water bath curing for 2 hours at $95^{\circ} \mathrm{C}$ ) 150 bar shapes specimenswere prepared to be used in this study. 50 specimenswere used for each test [flexural strength (group A), fracture toughness (group B), and hardness (group C)].

Grouping of the specimens:

Each group was further divided into five subgroups (1, 2, 3, 4 and 5) of 10 specimens each as shown in Table 1 .

\subsection{Flexural Strength}

Specimens were tested by 3-point bend test on Lloyd universal testing machine (model LRX plus II, Fareham, England) at a cross head speed of $1 \mathrm{~mm} / \mathrm{min}$. For the 3 point bend test, a fixture was fabricated with the 
Table 1. Classification and grouping of the specimens.

\begin{tabular}{|c|c|c|c|}
\hline Groups & Subgroups & Description & No. of Specimens \\
\hline \multirow{6}{*}{ Group A } & Group A1 & Heat-cure acrylic resin (PMMA) without additives as control. & 10 specimens \\
\hline & Group A2 & PMMA with $1.5 \%$ zirconium oxide nanofillers powder $\left(\mathrm{ZrO}_{2}\right)$. & 10 specimens \\
\hline & Group A3 & PMMA with $3 \% \mathrm{ZrO}_{2}$. & 10 specimens \\
\hline & Group A4 & PMMA with $5 \% \mathrm{ZrO}_{2}$. & 10 specimens \\
\hline & Group A5 & PMMA with $7 \% \mathrm{ZrO}_{2}$. & 10 specimens \\
\hline & Group B1 & PMMA without additives as control. & 10 specimens \\
\hline \multirow{3}{*}{ Group B } & Group B2 & PMMA with $1.5 \% \mathrm{ZrO}_{2}$. & 10 specimens \\
\hline & Group B3 & PMMA with 3\% $\mathrm{ZrO}_{2}$. & 10 specimens \\
\hline & Group B4 & PMMA with $5 \% \mathrm{ZrO}_{2}$. & 10 specimens \\
\hline \multirow{7}{*}{ Group C } & Group B5 & PMMA with $7 \% \mathrm{ZrO}_{2}$. & 10 specimens \\
\hline & Group C1 & PMMA without additives as control. & 10 specimens \\
\hline & Group C2 & PMMA with $1.5 \% \mathrm{ZrO}_{2}$. & 10 specimens \\
\hline & Group C3 & PMMA with 3\% $\mathrm{ZrO}_{2}$. & 10 specimens \\
\hline & Group C4 & PMMA with 5\% $\mathrm{ZrO}_{2}$. & 10 specimens \\
\hline & Group C5 & PMMA with $7 \% \mathrm{ZrO}_{2}$. & 10 specimens \\
\hline & & Total & 150 specimens \\
\hline
\end{tabular}

dimensions of $50 \times 30 \times 30 \mathrm{~mm}$ [15]. On top of the fixture two plates were welded at a distance of $15 \mathrm{~mm}$ from the center on either side. A customized " $T$ " shaped stress applicator rod with the dimension of $80 \times 20 \mathrm{~mm}$ was fabricated, by which stress can be applied in the center of the specimen. The specimen was placed on the rollers in such a way that the center of the specimen coincided with the center of the distance between the two rollers. This whole unit was mounted on the lower jaw of the universal testing machine and the stress applicator rod was fixed on the upper jaw. A load was applied with " $T$ " shaped rod on the center of the specimen until fracture occurred and peak force (F) values were recorded at this point in Newton [16].

The maximum force $(F)$ necessary to produce fracture of the specimens was recorded in Newton. The flexural strength Q was calculated in (MPa) for all specimens from the "Equation (1)":

$$
Q=\frac{3 F I}{2 B H^{2}}
$$

"In this formula, " $F$ " is the maximum load or force which is applied to the center of the specimen to fracture it $(\mathrm{N})$; " $I$ " is the distance between the two rests on the surface under the tensile force (mm); " $B$ " is the width $(\mathrm{mm})$ and " $H$ " is the height of the specimen between the surfaces under the tensile and compressive forces (mm).”

\subsection{Fracture Toughness}

For fracture toughness testing, specimens were fabricated with the dimensions of $50 \times 30 \times 30 \mathrm{~mm}$ [15]. After all specimens were stored in distilled water at $37^{\circ} \mathrm{C}$ for 24 hours, a notch was made in the middle of each specimen on one edge with $2.5 \mathrm{~mm}$ lengths using sand paper disk. Fracture toughness tests were performed on Lloyd universal testing machine (model LRX plus II, Fareham, England) with a cross-head speed of $1 \mathrm{~mm} / \mathrm{min}$, and peak load to fracture was recorded. The recorded data were used to determine the fracture toughness $\left(\mathrm{K}_{\mathrm{Ic}}\right)$ in MPa.m ${ }^{1 / 2}$ according to the "Equation (2)” [17]:

$$
K_{i c}=p c / b w^{1 / 2} \cdot F(a / w)
$$


where $p c$ is the maximum load $(\mathrm{kN})$ prior to crack advance, $b$ is specimen thickness $(\mathrm{cm}), w$ is the width of the specimen (cm), $a$ is crack length (cm) and $F$ is calculated from the following Equation (3):

$$
F_{(a / w)}=\frac{(2+a / w)\left(0.886+a / w-13.32 a^{2} / w^{2}+a^{3} / w^{3}-5.6 a^{4} / w^{4}\right)}{(1-a / w)^{3 / 2}}
$$

\subsection{Hardness}

For Hardness testing, specimens were fabricated with the dimensions of $15 \times 15 \times 5 \mathrm{~mm}$ [18]. Surface hardness was determined using Digital Display Vickers Microhardness Tester (Model HVS-50, Laizhou Huayin Testing Instrument Co., Ltd. China) which is suitable for acrylic resin material. With a Vickers diamond indenter and a $20 \times$ objective lens. A load of 20 gram was applied to the surface of the specimens for 15 sec. five indentations were equally placed over a specimen and not closer than $1 \mathrm{~mm}$ to the adjacent indentations or to the margin of the specimens were made on the surface of each specimen. The diagonal length of the indentations was measured by built in scaled microscope.

Surface microhardness calculation:

Vickers microhardness was obtained using the following Equation (4):

$$
V H N=1.854 L / d^{2}
$$

where:

VHN: Vickers hardness in $\mathrm{Kg} / \mathrm{mm}^{2}$.

$L$ : Load in Kg.

$d$ : Length of the diagonals in mm.

The recorded values of flexural strength, fracture toughness, and hardness were collected, tabulated and statistically analyzed. One way analysis of variance (ANOVA) and Tukey's tests were used for testing the significance between the means of tested groups which are statistically significant when the $\mathrm{P}$ value $\leq 0.05$.

\section{Results}

\subsection{Flexural Strength}

Both Table 2 and Figure 1 show a comparison between mean flexural strength in (MPa) of the tested groups of PMMA. ANOVA test showed statistically significant difference between all groups.

PMMA specimen with 7\% zirconium oxide nanofillers $\left(\mathrm{ZrO}_{2}\right)$ (group E) showed significantly highest mean flexural strength followed by PMMA specimen with $5 \%\left(\mathrm{ZrO}_{2}\right.$, group D) followed by PMMA specimen with 3\% $\left(\mathrm{ZrO}_{2}\right.$, group $\left.\mathrm{C}\right)$ then PMMA specimen with $1.5 \%\left(\mathrm{ZrO}_{2}\right.$, group B). There were significant differences $(\mathrm{P}<0.05)$ between studied groups. PMMA specimen without any additives (control group) showed significantly lowest mean flexural strength.

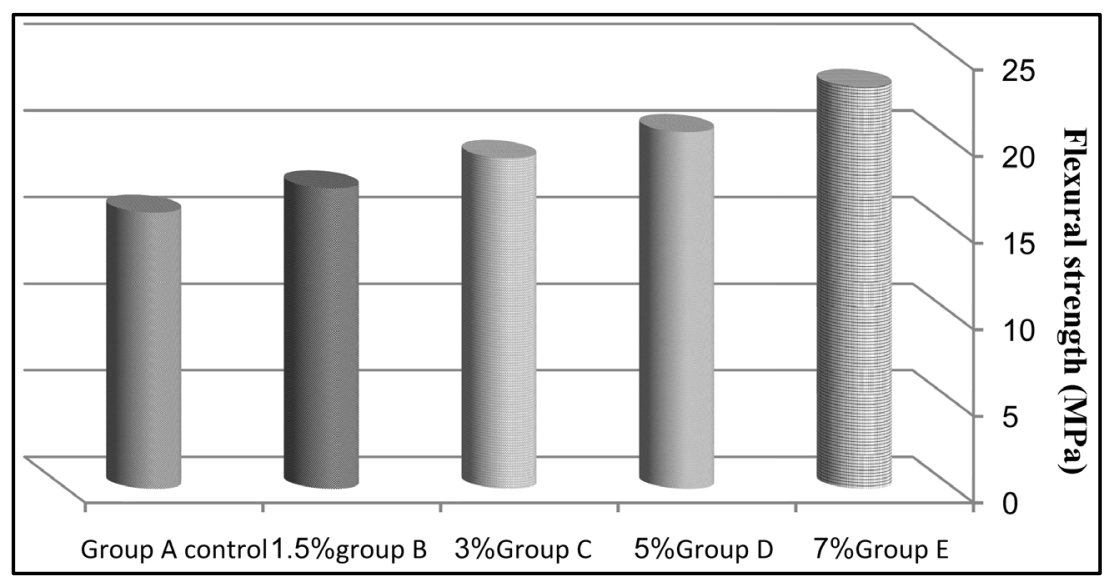

Figure 1. Bar chart of mean flexural strength (MPa) of the tested groups of PMMA. 
Table 2. Comparison between mean flexural strength (MPa) of the tested groups of PMMA.

\begin{tabular}{|c|c|c|c|c|c|c|c|c|c|c|}
\hline \multicolumn{2}{|c|}{$\begin{array}{c}\text { Group A1 } \\
\text { Control group }\end{array}$} & \multicolumn{2}{|c|}{$\begin{array}{c}\text { Group A2 } \\
\left(1.5 \% \mathrm{ZrO}_{2}\right)\end{array}$} & \multicolumn{2}{|c|}{$\begin{array}{l}\text { Group A3 } \\
\left(3 \% \mathrm{ZrO}_{2}\right)\end{array}$} & \multicolumn{2}{|c|}{$\begin{array}{l}\text { Group A4 } \\
\left(5 \% \mathrm{ZrO}_{2}\right)\end{array}$} & \multicolumn{2}{|c|}{$\begin{array}{l}\text { Group A5 } \\
\left(7 \% \mathrm{ZrO}_{2}\right)\end{array}$} & \multirow{2}{*}{ P-value } \\
\hline Mean & SD & Mean & SD & Mean & SD & Mean & SD & Mean & SD & \\
\hline $85.54^{\mathrm{e}}$ & 1.145 & $95.18^{\mathrm{d}}$ & 4.46 & $105.24^{\mathrm{c}}$ & 3.63 & $116.04^{\mathrm{b}}$ & 3.028 & $123.72^{\mathrm{a}}$ & 1.96 & $0.000^{*}$ \\
\hline
\end{tabular}

${ }^{*}$ Significant at $\mathrm{P} \leq 0.05$, Means with different letters are significantly different according to Tukey's test.

\subsection{Fracture Toughness}

The tensile strength data showed there was significant improvement in the tested groups which were reinforced with zirconium oxide nanofillers $\left(\mathrm{ZrO}_{2}\right)$ (Table 3 and Figure 2).

There was significant increase in the fracture toughness for groups reinforced with $(1.5 \%, 3 \%, 5 \%$ and $7 \%)$ $\mathrm{ZrO}_{2}$ when compared with control group.

\subsection{Hardness}

Both Table 4 and Figure 3 show the mean hardness of tested groups. All specimens showed hardness mean values higher than that control group. PMMA specimen with 7\% zirconium oxide nanofillers $\left(\mathrm{ZrO}_{2}\right)$ (group E) showed significantly highest mean hardness followed by PMMA specimen with $5 \%\left(\mathrm{ZrO}_{2}\right)$ (group D) followed by PMMA specimen with $3 \%\left(\mathrm{ZrO}_{2}\right)$ (group C) then PMMA specimen with $1.5 \%\left(\mathrm{ZrO}_{2}\right)$ (group B). There were significant differences $(\mathrm{P}<0.05)$ between studies groups. PMMA specimen without any additives (control group) showed significantly lowest mean hardness.

\section{Discussion}

We principally aimed to assess possible improvements in the mechanical properties of PMMA, in particular, the FS, fracture toughness, and hardness, through incorporating of $\mathrm{ZrO}_{2}$ Nano particles. There are three ways to improve the mechanical properties of PMMA: replacing PMMA with an alternative material; chemically modifying it; and reinforcing the PMMA with other materials [19] [20].

Addition of Zirconia Nano fillers to acrylic resin was found to improve mechanical properties. In addition to that $\mathrm{ZrO}_{2}$ was used because it has excellent biocompatibility and white color which less likely to alter esthetic. The Nano-filler particles were used in this study as it yield a better dispersion, eliminate aggregation and improve its compatibility with organic polymer [21] [22]. Proper percentage range of zirconiumoxide Nano-fillers (Percentages of $1.5 \%$ - $7 \%$ by weight) was selected because percentages above $7 \%$ was leads to massive changes occurred in the color of acrylic [23].

Fractures in an acrylic denture base are a common clinical problem. Flexural strength of denture base resin was measured in this study because it is considered the primary mode of clinical failure [24]. Fatigue failure does not require strong biting forces as relatively small stresses caused by mastication over a period of time can eventually lead to the formation of a small crack, which propagates through the denture and results in a fracture. The maximal biting forces of a patient can reach up to $700 \mathrm{~N}$, but these values are reduced (100 - $150 \mathrm{~N})$ [25] with the removal of dentures. Denture fractures are essentially due to stress concentration and increased flexing [26]. Many authors found that the fracture toughness seems to be a suitable measurement to demonstrate the effects of resin modifications [27].

Hardness of the polymerized resin has been found to be sensitive to the residual monomer content in the resin material. Moreover, hardness measurement have been successfully used as an indirect method of evaluating polymerization depth of resin-based composite materials [28] and the degree of conversion of conventional heatpolymerizing and self-curing acrylic resins. In addition, hardness has been used to predict the wear resistance of dental materials [29].

The Results of the present study demonstrated a significant increase in flexural strength, fracture toughness, and hardness as the percentage of $\mathrm{ZrO}_{2}$ fillers increased. This improvement in mechanical properties could be attributed to the high interfacial shear strength between the nanofiller and resin matrix as a result of formation of cross-links or supra molecular bonding which cover or shield the nanofillers which in turn prevent propagation of crack, also complete wetting of the nanofillers by resin lead to increase in flexural strength, fracture toughness, and hardness as volume of filler increased [30]. 


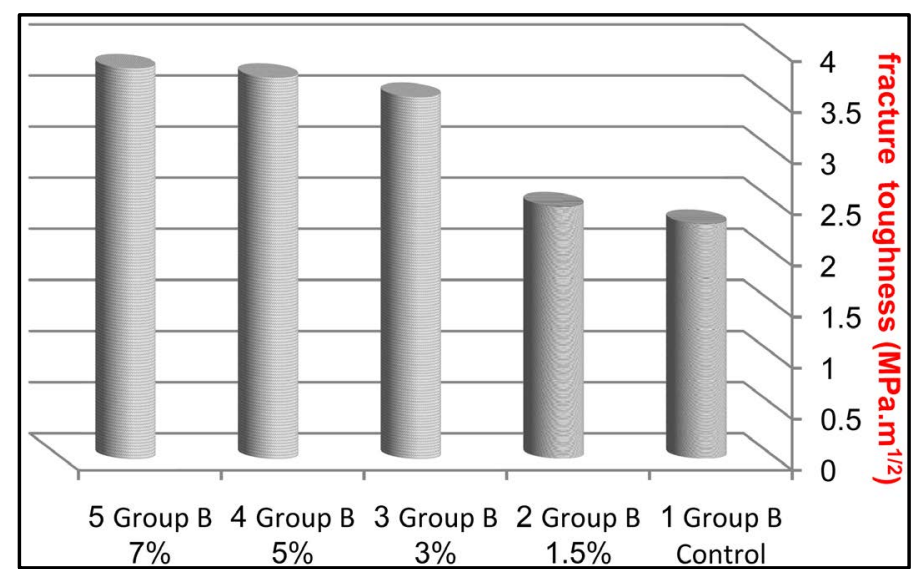

Figure 2. Bar chart of mean fracture toughness $\left(\mathrm{MPa} \cdot \mathrm{m}^{1 / 2}\right)$ of the tested groups of PMMA.

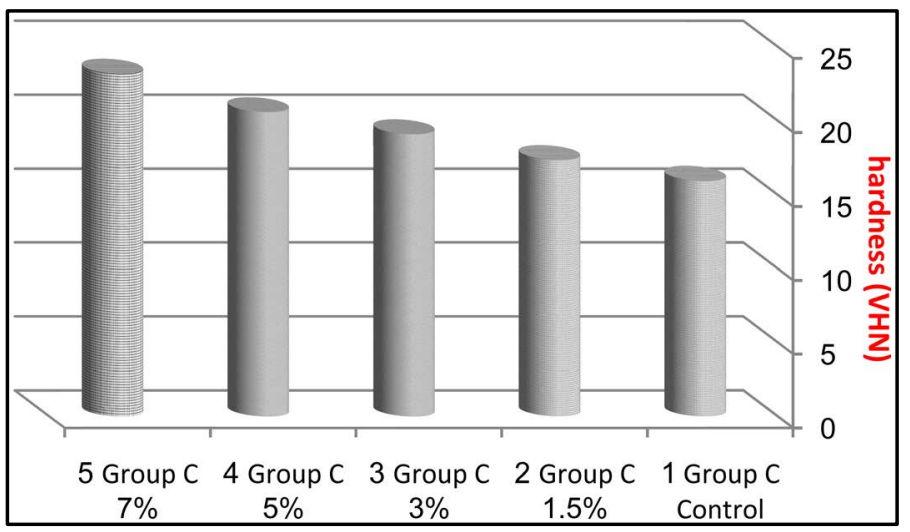

Figure 3. Bar chart of mean hardness (VHN) of the tested groups of PMMA.

Table 3. Comparison between mean fracture toughness $\left(\right.$ MPa. $\left.\mathrm{m}^{1 / 2}\right)$ of the tested groups of PMMA.

\begin{tabular}{|c|c|c|c|c|c|c|c|c|c|c|}
\hline \multicolumn{2}{|c|}{$\begin{array}{c}\text { Group B1 } \\
\text { Control group }\end{array}$} & \multicolumn{2}{|c|}{$\begin{array}{c}\text { Group B2 } \\
\left(1.5 \% \mathrm{ZrO}_{2}\right)\end{array}$} & \multicolumn{2}{|c|}{$\begin{array}{l}\text { Group B3 } \\
\left(3 \% \mathrm{ZrO}_{2}\right)\end{array}$} & \multicolumn{2}{|c|}{$\begin{array}{l}\text { Group B4 } \\
\left(5 \% \mathrm{ZrO}_{2}\right)\end{array}$} & \multicolumn{2}{|c|}{$\begin{array}{l}\text { Group B5 } \\
\left(7 \% \mathrm{ZrO}_{2}\right)\end{array}$} & \multirow{2}{*}{$P$-value } \\
\hline Mean & SD & Mean & SD & Mean & SD & Mean & SD & Mean & SD & \\
\hline $2.30^{\mathrm{b}}$ & 0.158 & $2.47^{\mathrm{b}}$ & 0.37 & $3.54^{\mathrm{a}}$ & 0.08 & $3.73^{\mathrm{a}}$ & 0.14 & $3.82^{\mathrm{a}}$ & 0.16 & $0.000^{*}$ \\
\hline
\end{tabular}

${ }^{*}$ Significant at $\mathrm{P} \leq 0.05$, Means with different letters are significantly different according to Tukey's test.

Table 4. Comparison between mean hardness (VHN) of the tested groups of PMMA.

\begin{tabular}{|c|c|c|c|c|c|c|c|c|c|c|}
\hline \multicolumn{2}{|c|}{$\begin{array}{c}\text { Group C1 } \\
\text { Control group }\end{array}$} & \multicolumn{2}{|c|}{$\begin{array}{c}\text { Group C2 } \\
\left(1.5 \% \mathrm{ZrO}_{2}\right)\end{array}$} & \multicolumn{2}{|c|}{$\begin{array}{l}\text { Group C3 } \\
\left(3 \% \mathrm{ZrO}_{2}\right)\end{array}$} & \multicolumn{2}{|c|}{$\begin{array}{l}\text { Group C4 } \\
\left(5 \% \mathrm{ZrO}_{2}\right)\end{array}$} & \multicolumn{2}{|c|}{$\begin{array}{l}\text { Group C5 } \\
\left(7 \% \mathrm{ZrO}_{2}\right)\end{array}$} & \multirow{2}{*}{ P-value } \\
\hline Mean & SD & Mean & SD & Mean & SD & Mean & SD & Mean & SD & \\
\hline $15.95^{\mathrm{c}}$ & 0.96 & $17.35^{\mathrm{c}}$ & 0.63 & $19.10^{\mathrm{b}}$ & 1.07 & $20.60^{\mathrm{b}}$ & 0.56 & $23.19^{\mathrm{a}}$ & 1.05 & $0.000^{*}$ \\
\hline
\end{tabular}

${ }^{*}$ Significant at $\mathrm{P} \leq 0.05$, Means with different letters are significantly different according to Tukey's test.

It is noted also from these results that concentration of $\mathrm{ZrO}_{2}$ (3\%wt) lead to the maximum value of fracture toughness. There is no significant improvement in fracture toughness values of the modified acrylic resin at the concentrations of $\mathrm{ZrO}_{2}$ above that limit (5\%wt and 7\%wt). It is probably due to complete saturation of the polymer matrix with the $\mathrm{ZrO}_{2}$ particles [31]. 
Improvement of hardness with the increase in concentration of $\mathrm{ZrO}_{2}$ nanofillers may have be due to inherent characteristics of the $\mathrm{ZrO}_{2}$ particles. $\mathrm{ZrO}_{2}$ possesses strong ionic interatomic bonding, giving rise to its desirable material characteristics, that is, hardness and strength.

The results of this study are in good agreement with the findings reported by others who concluded that reinforcement of ceramics, dental restorative resins as well as acrylic resin with Zirconia nanoparticles could exhibit improvement in their mechanical properties [31]-[33]. The increase of mechanical properties was due to good bonding between nanofillers and resin matrix [34] [35].

\section{Conclusions}

Within the limitation of this study, we can conclude that:

Addition of zirconium oxide nanofillers to PMMA increased the flexural strength, fracture toughness, and hardness of heat polymerized acrylic resin. According to the results of the present study, the best result was got when using the concentration of 7\%wt.

Further studies are needed to investigate its effect on other mechanical and physical properties with different concentrations.

\section{References}

[1] Nejatian, T., Johnson, A. and Van Noort, R. (2006) Reinforcement of Denture Base Resin. Advances in Science and Technology, 49, 124-129. http://dx.doi.org/10.4028/www.scientific.net/AST.49.124

[2] Darbar, U.R., Huggett, R. and Harrison, A. (1994) Denture Fracture-A Survey. British Dental Journal, 176, $342-345$. http://dx.doi.org/10.1038/sj.bdj.4808449

[3] John, J., Gangadhar, S.A. and Shah, I. (2001) Flexural Strength of Heat-Polymerized Polymethyl Methacrylate Denture Resin Reinforced with Glass, Aramid, or Nylon Fibers. Journal of Prosthetic Dentistry, 86, 424-427. http://dx.doi.org/10.1067/mpr.2001.118564

[4] El-Sheikh, A.M. (2006) SBA-Z: Causes of Denture Fracture: A Survey. Saudi Dental Journal, 18, 149-154.

[5] Vallittu, P.K., Alakuijala, P., Lassila, V.P., et al. (1994) In Vitro Fatigue Fracture of an Acrylic Resin-Based Partial Denture: An Exploratory Study. The Journal of Prosthetic Dentistry, 72, 289-295. http://dx.doi.org/10.1016/0022-3913(94)90342-5

[6] Kanie, T., Fujii, K., Arikawa, H., et al. (2000) Flexural Properties and Impact Strength of Denture Base Polymer Reinforced with Woven Glass Fibers. Dental Materials, 16, 150-158. http://dx.doi.org/10.1016/S0109-5641(99)00097-4

[7] Knott, N.J. (1989) The Durability of Acrylic Complete Denture Bases in Practice. Quintessence International, 20, 341343.

[8] Balch, J.H., Smith, P.D., Marin, M.A., et al. (2013) Reinforcement of a Mandibular Complete Denture with Internal Metal Framework. Journal of Prosthetic Dentistry, 109, 202-205. http://dx.doi.org/10.1016/S0022-3913(13)60045-1

[9] Venkat,, R., Gopichander, N. and Vasantakumar, M. (2013) Comprehensive Analysis of Repair/Reinforcement Materials for Polymethyl Methacrylate Denture Bases: Mechanical and Dimensional Stability Characteristics. The Journal of Indian Prosthodontic Society, 13, 439-449.

[10] Xu, J., Li, Y., Yu, T., et al. (2013) Reinforcement of Denture Base Resin with Short Vegetable Fiber. Dental Materials, 29, 1273-1279. http://dx.doi.org/10.1016/j.dental.2013.09.013

[11] Franklin, P., Wood, D.J. and Bubb, N.L. (2005) Reinforcement of Poly(methyl methacrylate) Denture Base with Glass Flake. Dental Materials, 21, 365-370. http://dx.doi.org/10.1016/j.dental.2004.07.002

[12] Asar, N.V., Albayrak, H., Korkmaz, T., et al. (2013) Influence of Various Metal Oxides on Mechanical and Physical Properties of Heat-Cured Polymethyl Methacrylate Denture. The Journal of Advanced Prosthodontics, 5, 241-247. http://dx.doi.org/10.4047/jap.2013.5.3.241

[13] Mohamed, A. and Mohamed, A., Fallal, A. and Hawary, Y. (2007) Effect of Zirconium Oxide Reinforcement on Epithelial Oral Mucosa, Immunoglobulin and Surface Roughness of Complete Acrylic Heat-Cured Denture. Egyptian Dental Journal, 53, 941-946.

[14] Skukla, S. and Seal, S. (2003) Phase Stabilization in Nanocrystalline Zirconia. Reviews on Advanced Materials Science, 5, 117-120.

[15] Kamble, V.D., Parkhedkar, R.D. and Mowade, T.K. (2012) The Effect of Different Fiber Reinforcements on Flexural Strength of Provisional Restorative Resins: An In-Vitro Study. The Journal of Advanced Prosthodontics, 4, 1-6. http://dx.doi.org/10.4047/jap.2012.4.1.1 
[16] Dagar, S., Pakhan, A. and Tunkiwala, A. (2005) An in Vitro Evaluation of Flexural Strength of Direct and Indirect Provisionalization Materials. Journal of Indian Prosthodontic Society, 5, 132-135. http://dx.doi.org/10.4103/0972-4052.17105

[17] Yilmaz, C. and Korkmaz, T. (2007) The Reinforcement Effect of Nano and Microfillers on Fracture Toughness of Two Provisional Resin Materials. Materials and Design, 28, 2063-2070. http://dx.doi.org/10.1016/j.matdes.2006.05.029

[18] Osada, T., Ishimoto, T., Aoki, T., Suzuki, Y., Ohkubo, C. and Hosoi, T. (2010) Bending Strengths and Hardness of Autopolymerized Acrylic Resin. International Chinese Journal of Dentistry, 10, 1-5.

[19] Kim, S.H. and Watts, D.C. (2004) The Effect of Reinforcement with Woven E-Glass Fibers on the Impact Strength of Complete Dentures Fabricated with High-Impact Acrylic Resin. The Journal of Prosthetic Dentistry, 91, 274-280. http://dx.doi.org/10.1016/j.prosdent.2003.12.023

[20] Jagger, D.C., Harrison, A. and Jandt, K.D. (1999) The Reinforcement of Dentures. Journal of Oral Rehabilitation, 26, 185-194. http://dx.doi.org/10.1046/j.1365-2842.1999.00375.x

[21] Suna, L.Y., Gibson, R.F., Gordaninejad, F. and Suhr, J. (2009) Energy Absorption Capability of Nanocomposites: A Review. Composites Science and Technology, 69, 2392-2409. http://dx.doi.org/10.1016/j.compscitech.2009.06.020

[22] Ihab, N.S., Hasanayn, K.A. and Ali, N.A. (2012) Assessment of Zirconium Oxide Nano-Fillers Incorporation and Silanation on Impact, Tensile Strength and Color Alteration of Heat Polymerized Acrylic Resin. Journal of Baghdad College of Dentistry, 24, 36-42.

[23] Shi, J.M., Bao, Y.Z., Huang, Z.M. and Weng, Z.X. (2004) Preparation of Poly (Methyl Methacrylate)/Nanometer Calcium Carbonate Composite by in Situ Emulsion Polymerization. Journal of Zhejiang University Science A, 5, 709-713. http://dx.doi.org/10.1631/jzus.2004.0709

[24] Chitchumnong, P., Brooks, S.C. and Stafford, G.D. (1989) Comparison of Three- and Four-Point Flexural Strength Testing of Denture-Base Polymers. Dental Materials, 5, 2-5. http://dx.doi.org/10.1016/0109-5641(89)90082-1

[25] Narva, K.K., Lassila, L.V.J. and Vallittu, P.K. (2005) Flexural Fatigue of Denture Base Polymer with Fiber-Reinforced Composite Reinforcement. Composites Part A, 36, 1275-1281. http://dx.doi.org/10.1016/j.compositesa.2005.01.025

[26] Franklin, P., Wood, D.J. and Bubb, N.L. (2005) Reinforcement of Poly(Methyl Methacrylate) Denture Base with Glass Flake. Dental Materials, 21, 365-370. http://dx.doi.org/10.1016/j.dental.2004.07.002

[27] Zappini, G., Kammann, A. and Wachter, W. (2003) Comparison of Fracture Tests of Denture Base Materials. Journal of Prosthetic Dentistry, 90, 578-585. http://dx.doi.org/10.1016/j.prosdent.2003.09.008

[28] Dunn, W.J. and Bush, A.C. (2002) A Comparison of Polymerization by Light-Emitting Diode and Halogen-Based Light-Curing Units. Journal of the American Dental Association, 133, 335-341. http://dx.doi.org/10.14219/jada.archive.2002.0173

[29] Lee, S.Y., Lai, Y.L. and Hsu, T.S. (2002) Influence of Polymerization Conditions on Monomer Elution and Microhardness of Autopolymerized Polymethyl Methacrylate Resin. European Journal of Oral Sciences, 110, 179-183. http://dx.doi.org/10.1034/j.1600-0722.2002.11232.x

[30] Ayad, N.M., Badawi, M.F. and Fatah, A.A. (2008) Effect of Reinforcement of High-Impact Acrylic Resin with Zirconia on Some Physical and Mechanical Properties. Revista de Clínica e Pesquisa Odontológica, 4, 145-151.

[31] Vojdani, M., Bagheri, R. and Khaledi, A.A.R. (2012) Effects of Aluminum Oxide Addition on the Flexural Strength, Surface Hardness, and Roughness of Heat-Polymerized Acrylic Resin. Journal of Dental Sciences, 7, 238-244. http://dx.doi.org/10.1016/j.jds.2012.05.008

[32] Giordano II, R. (2000) A Comparison of All-Ceramic Restorative Systems: Part 2. General Dentistry, 48, 38-40, 4345.

[33] Furman, B., Rawls, H.R., Wellinghoff, S., Dixon, H., Lankford, J. and Nicolella, D. (2000) Metal-Oxide Nanoparticles for the Reinforcement of Dental Restorative Resins. Critical Reviews in Biomedical Engineering, 28, 439-443. http://dx.doi.org/10.1615/CritRevBiomedEng.v28.i34.150

[34] Sun, L.Y., Gibson, R.F., Gordaninejad, F. and Suhr, J. (2009) Energy Absorption Capability of Nanocomposites: A Review. Composites Science and Technology, 69, 2392-2409. http://dx.doi.org/10.1016/j.compscitech.2009.06.020

[35] Tinschert, J., Natt, G., Mautsch, W., Augthun, M. and Spiekermann, H. (2001) Fracture Resistance of Lithium Disilicate-, Alumina-, and Zirconia-Based Three-Unit Fixed Partial Dentures: A Laboratory Study. International Journal of Prosthodontics, 14, 231-238. 